Document downloaded from:

http://hdl.handle.net/10251/60834

This paper must be cited as:

Hervás Oliver, JL.; Boix Domenech, R. (2012). The economic geography of the meso-global spaces: integrating multinationals and clusters at the local-global level. European Planning Studies. 21(7):1064-1080. doi:10.1080/09654313.2013.733853.

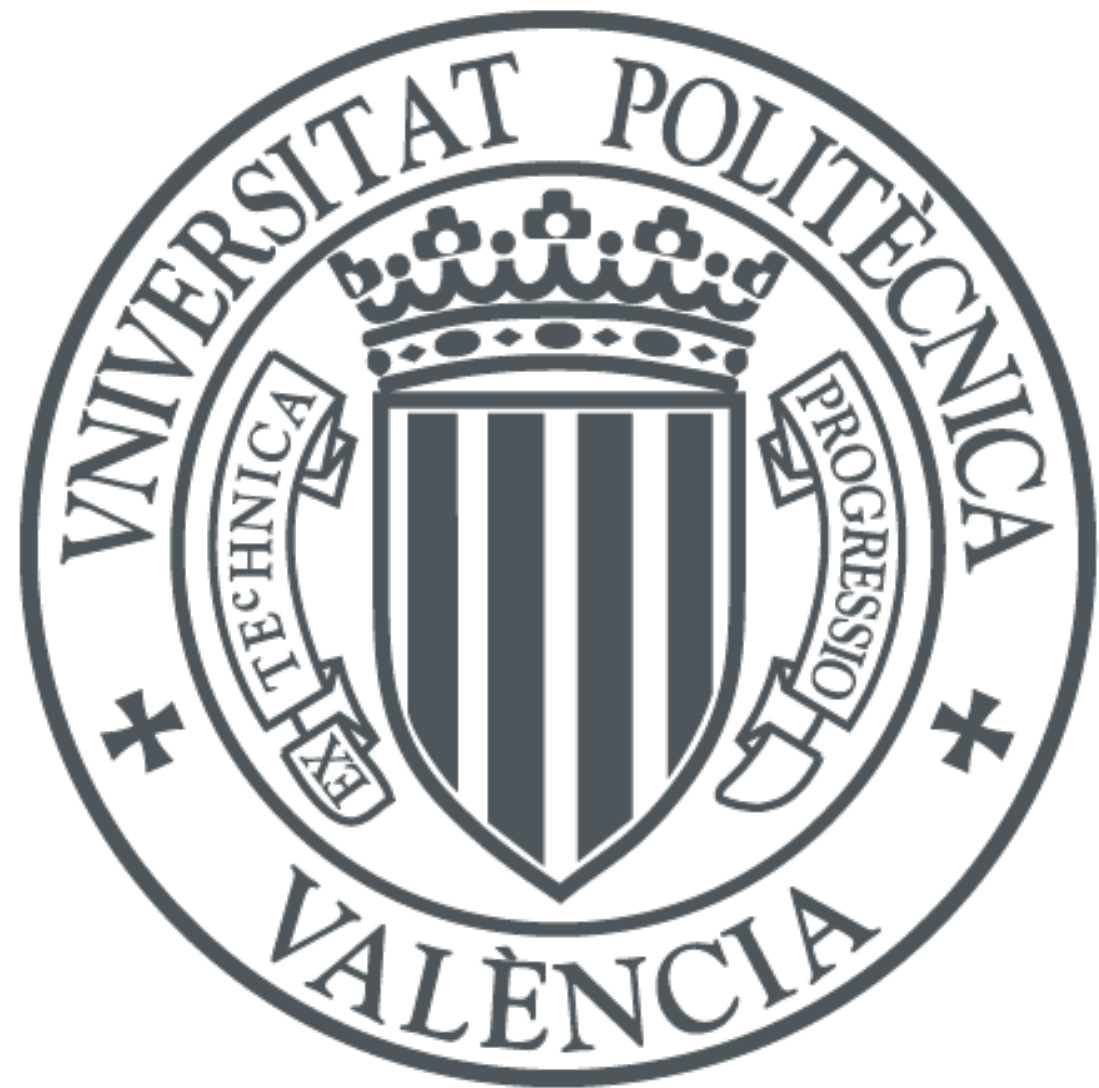

The final publication is available at

http://dx.doi.org/10.1080/09654313.2013.733853

Copyright Taylor \& Francis (Routledge): SSH Titles

Additional Information

This is an author's accepted manuscript of an article published in:

"European Planning Studies"; Volume 21, Issue 7, 2013; copyright Taylor \& Francis; available online at: http://dx.doi.org/10.1080/09654313.2013.733853 
This article was downloaded by: [Florida State University]

On: 23 November 2012, At: 07: 39

Publisher: Routledge

Informa Ltd Registered in England and Wales Registered Number: 1072954 Registered

office: Mortimer House, 37-41 Mortimer Street, London W1T 3J H, UK

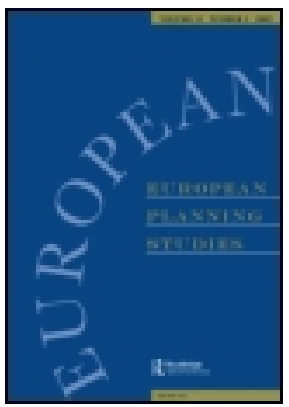

\section{European Planning Studies}

Publication details, including instructions for authors and subscription information:

http:// www.tandfonline.com/loi/ ceps20

The Economic Geography of the

Meso-global Spaces: Integrating

Multinationals and Clusters at the

Local-Global Level

Jose-Luis Hervas-Oliver ${ }^{a} \&$ Rafael Boix-Domenech ${ }^{b}$

${ }^{a}$ Management Department, Universidad Politecnica de Valencia, Valencia, Spain

${ }^{\mathrm{b}}$ Applied Economics Department, Facultat d'economia, Avda.Tarongers, Valencia University, Valencia, Spain Version of record first published: 30 Oct 2012.

To cite this article: J ose-Luis Hervas-Oliver \& Rafael Boix-Domenech (2012): The Economic Geography of the Meso-global Spaces: Integrating Multinationals and Clusters at the Local-Global Level, European Planning Studies, DOI: 10. 1080/ 09654313.2013.733853

To link to this article: http:// dx. doi.org/10.1080/09654313.2013.733853

\section{iFirst}

\section{PLEASE SCROLL DOWN FOR ARTICLE}

Full terms and conditions of use: http://www.tandfonline.com/page/terms-andconditions

This article may be used for research, teaching, and private study purposes. Any substantial or systematic reproduction, redistribution, reselling, loan, sub-licensing, systematic supply, or distribution in any form to anyone is expressly forbidden.

The publisher does not give any warranty express or implied or make any representation that the contents will be complete or accurate or up to date. The accuracy of any instructions, formulae, and drug doses should be independently verified with primary sources. The publisher shall not be liable for any loss, actions, claims, proceedings, demand, or costs or damages whatsoever or howsoever caused arising directly or indirectly in connection with or arising out of the use of this material. 


\title{
The Economic Geography of the Meso-global Spaces: Integrating Multinationals and Clusters at the Local-Global Level
}

\author{
JOSE-LUIS HERVAS-OLIVER* \& RAFAEL BOIX-DOMENECH** \\ *Management Department, Universidad Politecnica de Valencia, Valencia, Spain, **Applied Economics \\ Department, Facultat d'economia, Avda.Tarongers, Valencia University, Valencia, Spain
}

(Received April 2012; accepted September 2012)

\begin{abstract}
The local-global phenomenon literature is fragmented between the fields of international business and economic geography $(E G)$. In the case of the latter, the literature, produced within the global production networks (GPNs) and global value chain frameworks, does not address the central role of firms, especially multinationals which co-locate and connect territories along GPNs. This paper develops a cross-field conceptual integration in order to enrich the EG perspective, using qualitative research methodology to test the framework. The results have important implications for scholars and policymakers.
\end{abstract}

\section{Introduction}

The literature on clusters ${ }^{1}$ points out that they are local engines of growth, where co-located firms benefit from the presence of advanced assets and a particular combination of resources (see, e.g. Becattini, 1990). Local knowledge on clusters is formed from a continuous recombination of knowledge which occurs thanks to intense and repetitive social interactions in a context of rich and dense social capital (Storper \& Venables, 2004). Those interactions are influenced by knowledge external to the cluster (brought in through global pipelines or external linkages), which reinforces and complements locally generated knowledge (see, e.g. Bathelt et al., 2004). The local and non-local combinations of knowledge form unique repositories of knowledge or "knowledge domains" (Cooke, 2005) which foster innovation and provide an extra source of competitive advantage to local firms. The co-located firms each access the available local knowledge distinctly due to

Correspondence Address: Jose-Luis Hervas-Oliver, Universidad Politecnica de Valencia, Valencia 46022, Spain. Email: jose.hervas@omp.upv.es 
their different levels of absorptive capacity. Thus, the use value of local knowledge is not "free" in open space, but, is, rather, limited by each firm's capacity to learn and take advantage of it, which in turn is influenced by the fact that a certain threshold of resources is required before an enterprise can access the available cluster knowledge (Hervas-Oliver \& Albors-Garrigos, 2009).

The balance of the tension between the processes creating internal and external sources of knowledge is of particular importance for clusters which are constantly changing in response to the pressures of globalization. This local-global articulation has been addressed in the context of discussions of global pipelines (see, e.g. Bathelt et al., 2004) or external linkages (see, e.g. Hervas-Oliver \& Albors-Garrigos, 2008) and has also been referred to by writers within the global production networks (GPNs) framework (Coe et al., 2004; Henderson et al., 2002), but in general there has been poor attention paid to the firms (Coe et al., 2008) which facilitate those external flows of knowledge or external linkages. Put differently, the dialogue between organizations and places has been systematically under-researched in the field of economic geography (EG) (see, e.g. Beugelsdijk et al., 2010; Storper, 2009).

The lack of a clear and integrated conceptual body describing how internal and external sources of knowledge are combined thanks to local-global connections results from the theoretical fragmentation between schools of thought coming from a range of different perspectives (Beugelsdijk et al., 2010), including, for example, that of international business (IB) and strategic management (e.g. Dunning, 2009; Tallman \& Chacar, 2011) and EG (see, e.g. Bathelt et al., 2004; Belussi \& Asheim, 2010; Cooke, 2005; Gertler \& Levitte, 2005; Hervás-Oliver et al., 2008). It is because it is asserted that MNEs are key actors for connecting territories (see, e.g. Cooke, 2005; Dunning, 2009; McCann \& Mudambi, 2004), and that they are the main conveyors of information and knowledge, and for articulating global pipelines (Cooke, 2005; Nachum \& Keeble, 2003a,b), that it is necessary to insert the role of the MNEs into the EG perspective on clusters, thereby complementing the GPN approach. This is achieved in this paper by borrowing concepts and ideas from the IB literature. In parallel, this paper addresses a manifest lack of systematization, and it responds to the observation made by Beugelsdijk et al. (2010) that none of the aforementioned literatures explicitly focuses on how a firm's organizational characteristics relate to its fundamental geographical characteristics. Therefore, a crucial aspect is a need to understand organizational and co-location decisions "in tandem", in order to fully comprehend how local-global articulation through GPNs occurs thanks to multinational firms co-locating in clusters.

The rationale for developing a cross-field conceptual integration is the fact that the roles of firms, and especially MNEs, are central to the local-global phenomenon but, yet, to the best of our knowledge, the EG literature has not sufficiently tackled this fact (Coe et al., 2008). In fact, through the specific lens of EG, the debate is particularly relevant given the fact that although the concept of the GPN tries to cover the "big picture"-in which local clusters, their networks, their coordination mechanisms and so forth are globally integrated at a meso-global level—it nevertheless fails to adequately consider the micro-level, that is, the specific firms within the networks. Overall, despite the existence of excellent case studies (see, e.g. Cooke, 2005) recognizing the role of external linkages (see, e.g. Bathelt et al., 2004; Gertler \& Levitte, 2005), the EG literature does not provide an explanation of "how" MNE subsidiaries tap into local resources, insert themselves into the organizational spaces of diverse territories (or clusters) and connect up different 
locations between which knowledge, information and production are exchanged, and thus serve to articulate GPNs. From the IB and strategic management literature concepts and evidence can be transferred for use in describing how MNEs and their networks are configured so as to articulate and drive global pipelines (Cooke, 2005; Nachum \& Keeble, 2003a, 2003b), which complement ideas emanating from the EG perspective and thereby contribute to a rich cross-fertilization (e.g. Beugelsdijk et al., 2010). In a nutshell, the potential contribution of this paper derives from the complementarity of the aforementioned strands of literature-both those of IB and EG using the global value chain (GVC) and GPN frameworks, the conceptual integration of which can provide an improved theoretical framework for better addressing the local-global connection.

After this introduction, there is a second section which presents a theoretical framework derived from integrating different strands of the literature. Then, a third section describes the GVC of the ceramic tile and glazing industry and also presents a real-life case study which empirically tests the new theoretical framework. Finally, the fourth section discusses some main points and makes some conclusions.

\section{The Meso-global Space: Beyond GPNs and GVCs}

\section{Global Value Chains and Global Production Networks: Articulating External Linkages}

The local-global connection, and the potential it provides to facilitate the transfer of knowledge to a focal cluster, has been referred to in discussions of links to "non-local sources of knowledge" (Gertler \& Levitte, 2005), and to "non-local knowledge flows" (Gertler \& Levitte, 2005), and the roles of "external ties" (Gereffi, 1994) and of "global pipelines" (Bathelt et al., 2004), among others. In this chain of thought, the GVC approach (e.g. Gereffi, 1994; Humphrey \& Schmitz, 2002; Nadvi \& Halder, 2005) reveals sets of ties between globally dispersed producers and global buyers, as well as internal linkages between cluster members (Gereffi, 1994), and highlights three features of any industry: the "linkages" or "governance mechanisms" in value chains, the distribution of "power" among the actors involved and the role played by "institutions". These types of governance relationships are: "market", "modular", "relational", "captive" and "hierarchy" (Gereffi et al., 2005). The GVC is a useful concept, although it does have major shortcomings, in particular the fact that it generally assumes the existence of leading firms (such as global buyers or strong suppliers) which have the roles of organizing and controlling the GVCs. The works that have been carried out within this strand of thought are mainly empirically driven ones (see, e.g. Gibbon \& Ponte, 2005; Talbot, 2002).

A complementary concept is that of the GPN, which has been defined as "the globally organized nexus of interconnected functions and operations by firms and non-firm institutions through which goods and services are produced and distributed" (Coe et al., 2004, p. 471). The GPN (Coe et al., 2008, pp. 272-274) exhibits two key differences from the GVC: (1) the latter is essentially a linear structure, while the GPN incorporates (horizontally) all kinds of network configurations; (2) the GVC focuses narrowly on the governance of inter-firm transactions, while the GPN encompasses all relevant sets of actors and relationships and allows for multiple local embeddedness. The GPN concept addresses the different social, political and cultural circumstances of transnational actors, and the connecting nodes and links that extend spatially across national and regional territories as well as the networks that comprise horizontal and vertical ties 
between firms. The GPN distinguishes between "territorial embeddedness" and "network embeddedness", and recognizes different articulations of power relationships (such as "corporate, institutional" and "collectively organized power", see Henderson et al., 2002), and also identifies where value is created. Following Weller (2008), the GPN includes non-firm actors in a network, recognizes a complex circulation of capital, knowledge and people (beyond just inputs and outputs) and brings into view the synergies that exist between different network or nodal stages. Despite an awareness of the need to analyse the role of the firm in the GPN (Coe et al., 2008, pp. 276-278), the protagonists of this perspective have under-researched it, being overly biased towards looking at transnational corporation-driven cases focused on the South (see, e.g. Murphy \& Schindler, 2011), and pursuing a mainly empirically driven approach.

Therefore, it is necessary to address in addition the roles of the main actors that connect clusters and which also engage in multiple embeddedness (Meyer et al., 2011): the MNEs. Knowledge transfer is important. It complements the "local buzz" (Storper \& Venables, 2004) and helps avoid inertia or lock-in (Maskell \& Malmberg, 2007). Knowledge transfer to a cluster occurs, basically, through the co-location of MNE subsidiaries, the headquarters of which, or other group subsidiaries, are in other clusters. Addressing the issue of co-location of firms is a way of tackling the shortcomings of the GPN approach (Coe et al., 2008): that is, by understanding the firm's role within the GPN, and what happens within the inter-firm sphere (which encompasses the creation and diffusion of knowledge within MNE headquarters, and between headquarters and subsidiaries, and also between subsidiaries, and between subsidiaries and local firms).

\section{Knowledge Distance in Clusters}

Knowledge transfer in the local-global connection is not free of frictions. As the GPN perspective recognizes, all local contexts (or clusters) are different. Each cluster or local node presents a different agglomeration and different interactions, and in sum, a completely different context. We address this fact by looking at the issue of knowledge in the cluster. A local cluster will absorb knowledge from other clusters or from MNEs, as long as the knowledge base necessary to understand (decode or interpret and then absorb) the new knowledge is similar to the existing one. The Tallman and Chacar (2011) model, which describes the way MNEs access local networks in order to tap into local knowledge, assumes that all knowledge has at least some "tacit" aspects. The "architectural knowledge" derived from common practice within a "context" must be experienced to be internalized and provides the understanding to absorb related component knowledge effectively (see Henderson \& Clark, 1990; Tallman et al., 2004). This model is based on the idea that architectural knowledge (common understandings which define a community of practice; Henderson \& Clark, 1990), based on common practice, is the framework which allows the exchange and mobility of tacit (component) knowledge within communities without codifying and decoding such component knowledge. For MNEs, the key sources of high-tacit content component knowledge come from MNE subsidiaries' communities of practice that are also embedded in local networks of practice, as Tallman and Chacar point out. Then, when subsidiaries are locally embedded, the local interaction with local firms and organizations can create particular firm-specific advantages (FSA) based on location-bound knowledge (Rugman \& Verbeke, 2001) due to the specific agglomeration effects, that is, the available knowledge in each particular 
cluster. This location-bound FSA is based in a subsidiary's repository of knowledge and is tacit and context specific (locally embedded), and is a knowledge difficult to diffuse internally to headquarters due to mobility barriers (Nelson \& Winter, 1982). However, a subsidiary can also create location-bound FSAs which, once made explicit, can be translated into non-location-bound FSAs and diffused throughout the MNE internal network. In this chain of thought, an MNE's subsidiaries act as "learning interfaces" (Belussi \& Asheim, 2010, p. 252) between knowledge architectures in circumstances of multiple embeddedness (Meyer et al., 2011), that is, in multiple territories.

It may be assumed that clusters' knowledge stock differences may work as isolating mechanisms in the process of knowledge diffusion between clusters (Pinch et al., 2003). This idea is confirmed in Jenkins and Tallman (2010) due to the differing cluster repository of knowledge. It is thought that the transfer and absorption of knowledge from one cluster or region is slowed by being inserted into another cluster or region which has a different architectural knowledge. ${ }^{2}$ The fact that clusters can have different knowledge architectures even in the same industry is illustrated by Nachum and Keeble (2003a, 2003b) who point out that the post-production knowledge domain found in Soho and based on small and free-lance companies is distinct from that of Hollywood. Cooke (2005) also distinguishes between different knowledge domains found in bioregions dedicated to agro-food, such as Guelph (Ontario) based on corn and the Skane food cluster (Sweden) based on functional food.

\section{Qualitative Research}

The research methodology used in the study on frits and glazing firms is qualitative, exploratory and holistic in nature (Eisenhardt, 1989; Yin, 2008). Our empirical base comprises primary data (interviews with managers, members of a trade association board and industry experts), and secondary sources (case studies in scientific journals, professional journals, industry reports, and information from firms' own web pages, and also Amadeus database exploration). The interviews were carried out over various sessions during 2011 with members from the board of directors of the Asociacion Nacional de Fritas, Esmaltes y Colorificios association (the glazing trade association in Castellon). In addition, during October managers from the most prominent Castellon MNEs in the glazing industry were interviewed on different occasions. The interviews covered a panel of 10 informed respondents (from the trade association board, managers and industry experts), carried out over a combined total period of roughly 40 hours.

\section{The Castellon and Sassuolo Clusters: Driving Innovation in the Ceramic GPN}

The ceramics value chain includes in particular four core actors: clay atomizers, ceramic producers, frits and glazing firms (chemicals), and equipment manufacturers. By 2010 China has kept growing and now controls around $68 \%$ of world production share (Anfacer, 2011), while Spain and Italy had shrunk to become followers with, respectively, $5.8 \%$ and $6 \%$ of the share. However, the Spanish and Italian clusters still accounted for roughly $80 \%$ of European production (down from $90 \%$ in 2000), with the remainder coming from around Aveiro in Portugal, and Staffordshire in the UK, and small shares from other countries such as Russia and Romania. In 2010, Spain accounted for 370 million square metres, falling from 600 million in 2002 (Ascer, 2010); and Sassuolo 
dropped to 400 million square metres in 2010 (Assopiastrelle, 2011) from around 600 million at the beginning of 2000 . This reflects a shift in production to the South, especially to Brazil, which produced 802 million square metres in 2010 (Anfacer, 2011), that is, roughly $11 \%$ of world production (increasing from $8.4 \%$ in 2004). In 2010, Brazilian ceramic tiles exports amounted to 60 million square metres, or around $7.5 \%$ of its production; $90 \%$ of its exports went to countries within South and Central America.

The Castellon cluster in Spain is a meta-cluster, with 300 firms in a range of different but related industries, providing 20,000 direct jobs in 2010 (Ascer, 2010). The cluster includes all the activities of the ceramic value chain, including also various public organizations such as those belonging to the network of technological institutes of the Valencia region-including the Institute of Ceramic Technology (ITC-ALICER, hereinafter)—and educational centres, such as the Jaume I University. The Spanish glazing industry is the most powerful auxiliary industry in the Castellon cluster (Hervas-Oliver \& AlborsGarrigos, 2008; Meyer-Stamer et al., 2004) and is the world leader, having extensive operations in other clusters including in Italy and Brazil.

Along with Spain, Italy also has one of the largest ceramic industries in the world. Around $80 \%$ of Italy's ceramic tile production is concentrated in the Emilia-Romagna region, around Sassuolo, where some 23,093 direct ceramic tile producing jobs are located (Assopiastrelle, 2011) — as well as a further 6000 jobs in supplier industries. There are around 300 firms (including 173 ceramic tile producers) and some others in related industries, showing a similar industrial organization to that of Castellon. The Emilia-Romagna region has a range of public institutions and agencies, such as the Centre of Ceramics of Bologna, as well as private bodies such as the industry trade association, Assopiastrelle. An important characteristic and strength of the Italian district is that it contains a strong ceramic tile machine manufacturing sector. These machine manufacturing firms lead the world and offer their innovations to Italian ceramic tile manufacturers, as well as to other producers worldwide (Hervás-Oliver et al., 2008).

According to Hervas-Oliver and Albors-Garrigos (2007, 2008), and Meyer-Stamer et al. (2004), the Italian companies are particularly pro-active downstream in respect of aspects such as marketing and design, and compete in the high-end segments, and maintain a more consistent reputation for quality than do other clusters. In contrast, the Spanish cluster companies tend to be less focused on product differentiation, serve lower segments and are more focused on upstream production aspects and on innovation related to the application of frits and glazes.

According to Meyer-Stamer et al. (2004) and Hervás-Oliver et al. (2008) both the Italian and Spanish clusters are well served organizationally, having enough public agencies (such as R\&D centres and educational institutions) and private actors (such as fairs and trade associations) to provide proper support to the value chain. However, support organizations, and their interactions with one another and with the industry, such as that of the ITC and its collaboration with the Jaume I Universitat, seem to work better in Castellon (Hervas-Oliver \& Albors-Garrigos, 2007, 2008; Meyer-Stamer et al., 2004). Indeed, the true strength of the Castellon cluster lies in its "systemic behaviour". A mechanism of innovation diffusion operates that is very difficult to replicate in a different context-as confirmed in interviews carried out while preparing this paper. Ceramic tile company technicians are in continuous contact with technicians from glazing companies. Moreover, ceramic tile companies hire chemical engineers specialized in ceramic tiles and trained at the ITC and the Jaume I Universitat. Accordingly, there is a 
dynamic information and knowledge flow within the cluster network system. This is why the glazing industry is the main signatory of contracts with the ITC and is the cluster sector with the most developed R\&D. Knowledge is transferred through its interrelations and links with tile companies. At the same time, these links are strengthened by the ITC's support for the tile companies and the hiring of technicians experienced in the various industries. This creates a fluid circulation of tacit and explicit knowledge. This process is aided by the use of a common language, culture, understanding and personal relationships of local workers-who are implicitly motivated by the same objectives (MeyerStamer et al., 2004). The innovation capacity and the circulation of tacit knowledge in the Italian cluster are also highly relevant (Russo, 2004).

Figure 1 shows the similar composition and structure of the Sassuolo and Castellon clusters, although their respective strengths and innovation dynamics are different, as aforementioned.

According to Albors-Garrigos and Hervas-Oliver (2012), in the Castellon cluster a major disruptive technology has been operating since the beginning of the 2000. Until 1994, the decorating process in the tile ceramics sector was mainly based on screen printing technology utilizing flat or cylinder screens, and since 1994 improved with the Italian Rotocolor ${ }^{\circledR}$ machine using laser engraved polyethylene rollers technology. Nowadays, this is the dominant design worldwide and this mature technology is used by roughly $90 \%$ of the producers in the emerging world. Since 2000 a new technology called INKJET has emerged, and includes inkjet print-heads for tile decoration. Consequently,

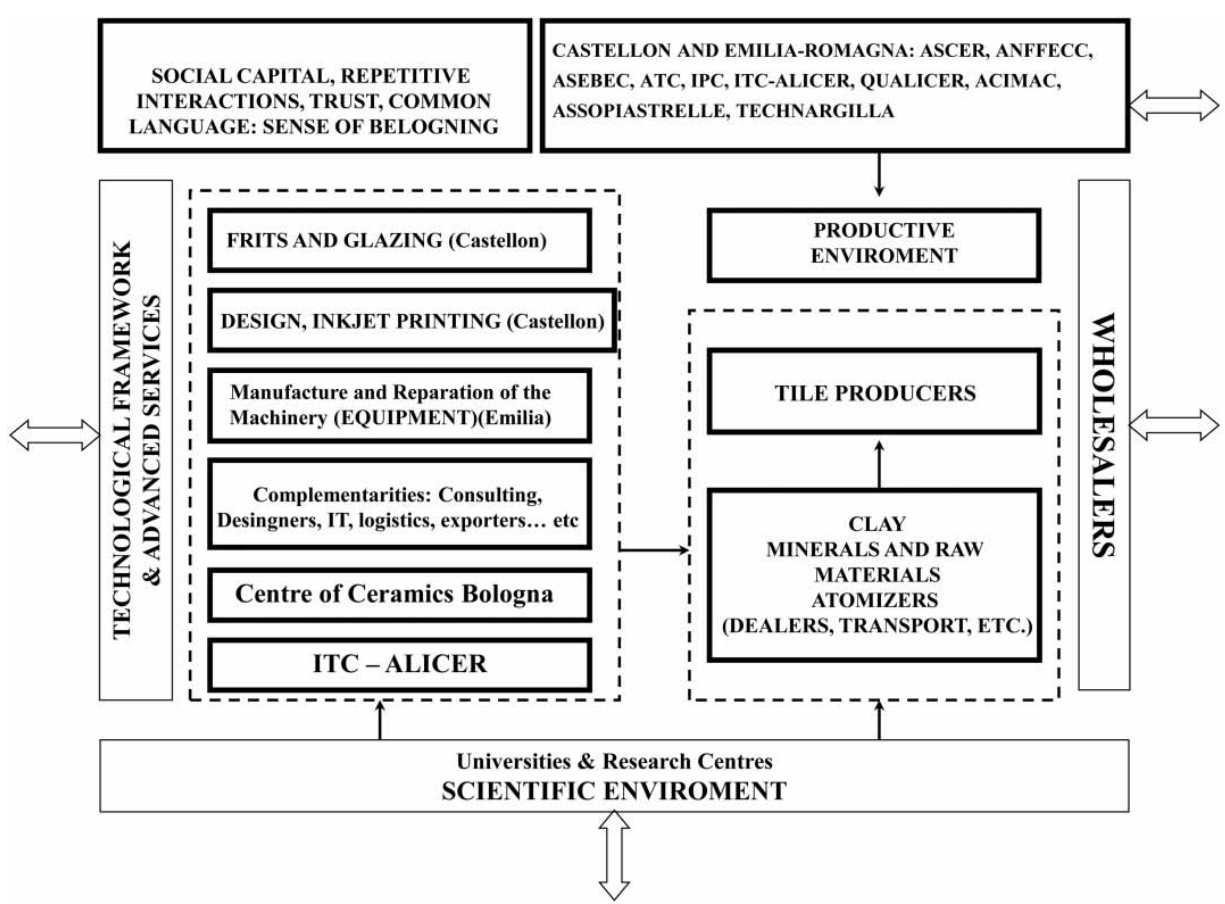

Figure 1. Composition and structure of the main European ceramic tiles clusters (Castellon and Sassuolo). 
(and after a substantial R\&D effort), special inks for tile ceramic decoration were developed by the main frits-glazing producers in Castellon which have now leapfrogged competitors not located in Castellon. Meanwhile, clusters elsewhere (in Brazil, Mexico and Asia) are still mainly focused on screen "architectural knowledge," but they are gradually adapting to the new inkjet technology thanks to flows of knowledge coming from the Castellon frits and glazing MNE subsidiaries co-located there, as explained below. The innovation in Castellon mainly originates from the frits and glazing industry, indicating a supplier-driven mode of innovation (in terms of Pavitt, 1984).

\section{Interviews: Knowledge Transfer Worldwide from Castellon}

The cluster has 26 firms specialized in frits, glaze and colour, with 3200 direct employees and an average size of 151 employees. According to the informants, the glazing industry in Castellon presents an interesting heterogeneity made up of three main types of firms. First, there are those which only work for the domestic market (i.e. small frits-glazing firms, which are price sensitive, and offer a narrow range of services, and are technology followers). Second, there are those which also provide services and design as part of their product offer, that is to say they complement frits work with consulting and advice on exporting to international markets and provide technical assistance in foreign destinations (i.e. they are technology advanced firms, of medium size, offering a wide range of services, and are innovative and intermittently research intensive, and with a focus on exporting). Third, there is the most "global" group which is formed by five MNEs (referred to as the "big five", hereafter): Colorobbia (an Italian firm based in Castellon), Torrecid (with Castellon equity), Esmalglass (with Castellon equity), Endeka (with UK and Castellon partners) and Ferro (having US shareholders). These are technology leaders, R\&D intensive, employing cutting edge technology, and are part of multinational groups. They act as global companies with a network of subsidiaries located in the most prominent clusters worldwide. They are the five world-class leading companies in the field, and are the key "technology gatekeepers", and include three (Torrecid, Esmalglass and Ferro) which have been the main actors in the development of the new organic inks for the inkjet technology revolution mentioned earlier.

The Castellon cluster accounts for around $40 \%$ of the world production of frits and glazing. All of the big five group are located there and contribute to around $70 \%$ of the cluster's international commerce of frits and glazes, and for around 50\% of Castellon's production. These big five companies have subsidiaries in all countries where the production of ceramic tiles is important. For instance, Esmalglass has affiliates in Italy, the UK, Portugal, Russia, Brazil, Indonesia and China. Colorobbia has affiliates in the same locations as Esmalglass, plus also Taiwan, Turkey and Mexico. Torrecid has affiliates in the same locations as Colorobbia, plus also Thailand, Vietnam and India (Figure 2(a) and (b)).

All these five companies initially relied on exporting from Castellon and then gradually established plants in foreign host locations, with clear implications and consequences. Thus, in 1990 Brazil took $2.88 \%$ of Castellon's exports, well behind Italy (37.4\%) or Portugal (17.18\%). In 2010 exports to Brazil disappeared from export figures, due to the fact that the exporting firms had off-shored production there. In addition, it is important to observe that production has gradually moved East, in parallel with stagnation in the West. By 2010, Italy only accounted for $15.76 \%$ of Spanish exports of frits and glazes 
(a)

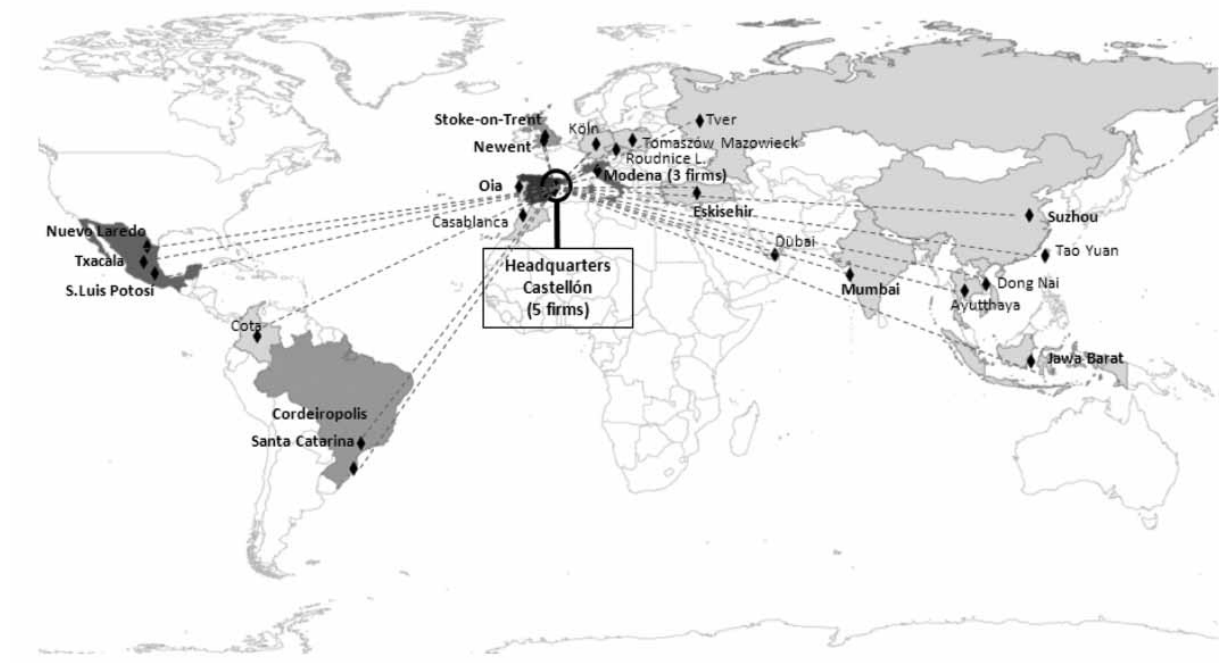

(b)

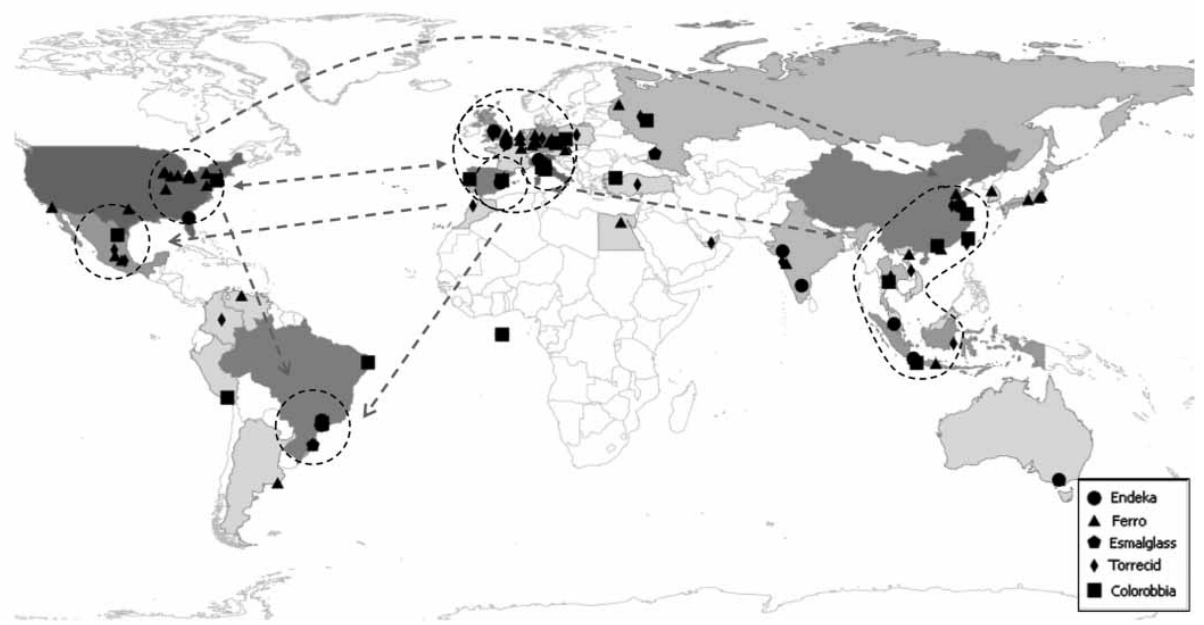

Figure 2. Subsidiaries along the ceramic tile GPN. (a) Torrecid. (b) Big five: Endeka, Ferro, Esmalglass, Torrecid and Colorobbia.

Source: Elaborated from the firms' corporate reports.

(declining from $37.4 \%$ in 1990), while Egypt and Turkey were by then taking $10.11 \%$ and $4.41 \%$, respectively, that is, they were now ranked second and third in Castellon's export destinations. The remainder of the emerging nations received minor shares of exports in 2010 due to the fact that production has been off-shored there by the leading Castellon frits-glazing firms.

For example, the Torrecid group has subsidiaries in 20 countries: 16 in Europe, 6 in Latin America, 7 in Asia and 1 in Morocco. Thanks to its technological advances, centralized in the Castellon (Spain) headquarters, the firm offers its customers a complete range 
of products that address their specific needs and which allows them to create final products that are more competitive and with higher value added, using mainly knowledge from Castellon. Each subsidiary receives knowledge from Castellon and thus the MNE connects the territories by operating in a context of multiple embeddedness (Figure 2(a) and (b)).

The interviews have confirmed the complementary links that exist between ceramic tile clusters in Castellon (Spain) and Sassuolo (Italy). These links started at the end of the 1980 when the Italian machinery sector developed the monolayer kilns which allowed the Castellon firms (such as Torrecid) to develop a breakthrough innovation using the "single fire process". Since then, the frits and glazing firms in Castellon have been knowledge-connected to the equipment firms in Sassuolo. The interviewees agreed with the idea that it is not a question of off-shoring entire firms, but, rather, specific activities that fit with the advantages to be found in each agglomeration or cluster. The highest value-adding activities, R\&D and fusion frits, are located in Castellon because it is the more efficient solution on account of the ability to make use of local production and knowledge advantages. Moreover, off-shoring such activities to Italy means not only losing out on utilizing the local knowledge resources for frits-glazing available in Castellon, but also risking potential problems associated with contributing too much to the host cluster through knowledge "spillovers".

Tacit knowledge in the Castellon cluster is generated locally through local inter-industry interaction, and this knowledge is partially transferred to the Italian cluster in three ways. First, four Italian glazing firms (three small players plus the global player Colorobbia) have co-located in Castellon while maintaining their headquarters in Sassuolo. However, despite retaining the Sassuolo headquarters, it is striking that R\&D and innovation activities are conducted in Castellon, where all of them produce frits and glazes, profiting from a more chemical knowledge-rooted environment. Secondly, the Castellon exports of frits and glazes to Italy are supported by Castellon MNE subsidiaries whose off-shored activities are basically of a technical and post-sale support leaving production and $\mathrm{R} \& \mathrm{D}$ activities to be concentrated in the Castellon knowledge domain. Consequently, the tacit (component) knowledge created in Castellon is gradually disseminated to Italy through the Castellon subsidiaries which focus on technical support to assist the exports of frits produced in Castellon. Thirdly, part of the tacit knowledge gained in Castellon by the Italian subsidiaries co-located there is disseminated to the Italian headquarters and to the Italian ceramic equipment industry. This innovation GVC, or inter-meso system of innovation, is a two-way street which ensures the diffusion of innovation and that the two clusters transfer from one to the other, in both directions, the very best knowledge. The implicit idea that the board of directors at the trade association had about being in the Italian cluster is crucial. Put differently, being there was the right thing, but the point is "how" the MNEs are off-shored there.

The picture completes with the incorporation of Brazilian and Asian clusters. Brazil is the second largest producer in the world, after China, equalling the combined total of Spanish (Castellon) and Italian (Sassuolo) production. Brazil is a major destination of the big five group, having subsidiaries in Santa Gertrudes (Endeka, Esmalglass, Colorobbia and Ferro) and Criciuma (Torrecid, Esmalglass and Colorobbia). All the five companies carry out frits high-temperature fusion there, that is, they own subsidiaries which produce in Brazil products similar to those made in their headquarters in their home countries; but they do not carry out R\&D and innovation activities there. 
Architectural knowledge in Brazil is based on traditional technology. Although "inkjet" is emerging step-by-step, Brazilian firms do not yet have the necessary absorptive capacity to assimilate all the knowledge from Castellon, and neither does the market in South and Central America require such advanced knowledge (or at least it will not pay for it!). Local adaptations are really important due to the fact that kiln temperatures, the specific granulation of clay and a lot of different production activities present dissimilarities with the Castellon way of working. Nevertheless, one advantage is the fact that the Brazilian clusters seem (in production and technological terms) similar to the Spanish and Italian clusters of the early 1990s. However, the need to adapt to local requirements (such as in respect of customs, standards and so forth) is important, and frequently the presence of a permanent team of engineers from Castellon is required to solve local problems with Castellon solutions. This is especially important regarding new inkjets applications for which most of the knowledge comes from Castellon.

Outside of Brazil, one of the most prominent clusters is the Surabaya cluster in Indonesia, which has around 70 ceramic tile firms. Colorobbia and Ferro carry out fusion frits there, while Esmalglass, Torrecid and Endeka produce commodities (glazes), exporting from Castellon the fusion frits. Most of the companies use Indonesia as an export platform to Malaysian manufacturers, although Endeka also has a subsidiary in the Negeri Sembilan (Malaysia) cluster. In addition, all the big five companies have subsidiaries in Turkey and Egypt, but they only provide technical support in foreign direct investment (FDI) sales activities and do not carry out production.

\section{Main Findings Regarding the EG of the Meso-global Spaces}

The evidence from the interviews described in Section 3.2 lead to the following implications regarding the EG of the meso-global spaces.

First, Italian glazing MNEs that are co-located in Castellon also co-locate their R\&D and innovation activities there in order to take advantage of the local externalities. Knowledge gained through this process is then diffused to the Italian headquarters. The chemicalbased architectural knowledge of the Castellon cluster involves knowledge spillovers which can be appropriated by co-located Italian MNEs. Moreover, the Castellon cluster acts as a hub for frits and glazing ceramics, with the highest concentration in Europe of frits companies and, especially, the greatest number of connections in the form of inflows and outflows of FDI (Figure 2(b)).

Second, the Castellon MNEs co-located in Sassuolo (Italy) only de-locate market support activities, due to the fact that there are no opportunities to gain from R\&D or innovation externalities in the Sassuolo cluster. However, the existence of equipment-based architectural knowledge in the Sassuolo cluster means that great knowledge spillovers occur thanks to the links between ceramic producers and equipment manufacturers, and knowledge from these spillovers can be appropriated by the sales branches of the Castellon MNEs.

Third, all in all, the context, understood as a configuration of a specific division of labour and set of networks in which actors find themselves, which influence the informational environment of individuals (Storper, 2009, p. 13), is completely different in each cluster. The Italian and Spanish contexts, each with its own type of ties and coordination mechanisms, together with a particular architectural knowledge, constitute good examples of the different meso-spaces which articulate and form a GPN. In addition, it is clear that 
the MNEs, which have their headquarters in each cluster, and affiliates in the other, are key agents for transferring knowledge and organizing the GPNs. It is through such insights that the contribution of the IB literature to that of the GPN and EG literatures can best be appreciated.

Two main results regarding the "emerging world" clusters arise.

First, MNE subsidiaries (frits firms belonging to the big five group) from Castellon colocate in different clusters worldwide and thus transfer knowledge of frits, glazing and the decorating process, from Castellon to Brazil, Indonesia or to other clusters. In each cluster, due to their differing contexts and architectural knowledge, the flows of knowledge (and its absorption) vary. Each meso-cluster occupies a stage in a GPN in which Castellon firms develop "network coordination" mechanisms (in the sense used in the GVC perspective) in respect to domestic firms. The MNE subsidiaries are the key integrators of the ceramic tiles GPN, taking the role of disseminating knowledge, and contribute to the equilibrium of each territory (or network stage). The fit between local cluster externalities and the FDI corresponds to the way in which the MNEs adapt to each stage (or cluster) of the GPN.

In addition, the above-mentioned MNEs also diffuse the new inkjet technology, although the spread and diffusion of this new technology depend on the architectural knowledge of each focal cluster. The diffusion of knowledge to clusters in Brazil, Indonesia or elsewhere is moderated by the specific context and architectural knowledge available in each cluster and, especially, to the demand requirements. For example, for emerging clusters high value-added products or sophisticated tiles do not form the majority of sales and are only a minor part of production.

All in all, it can be also said that

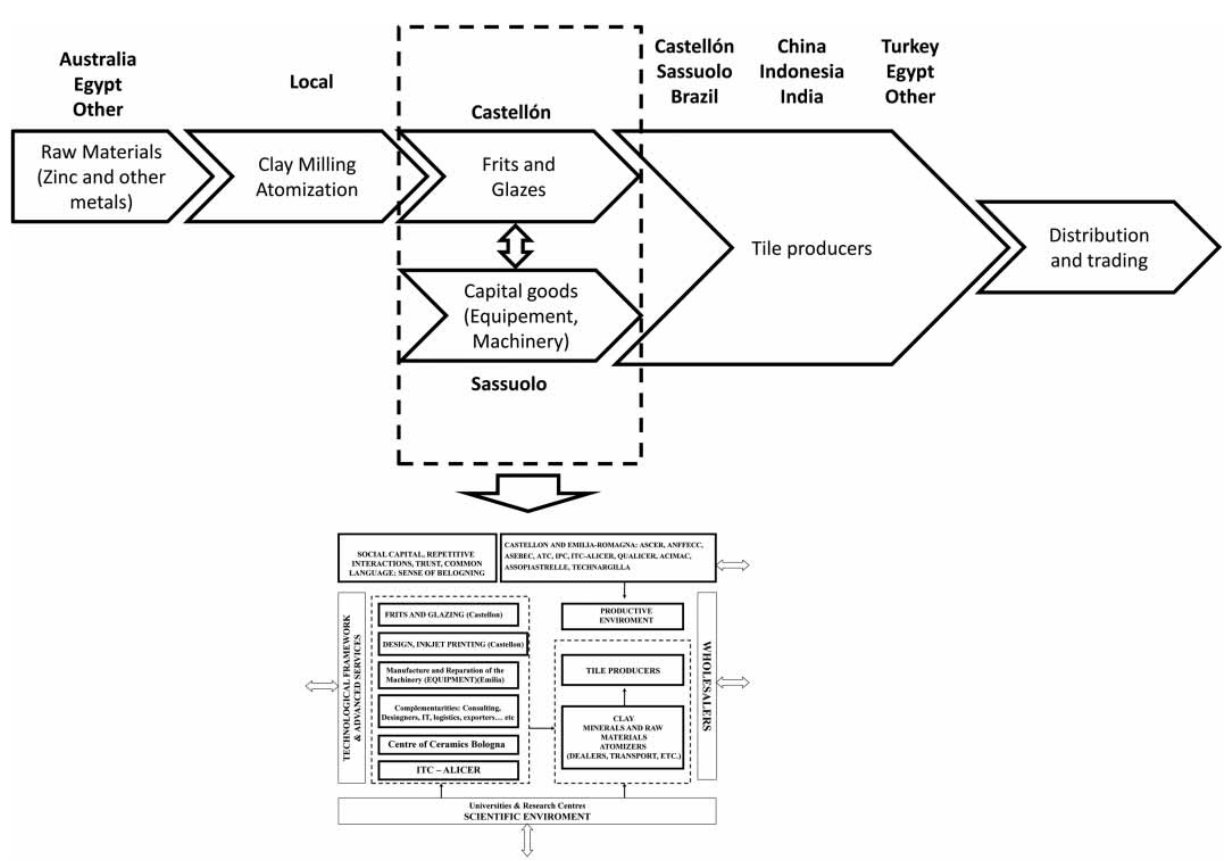

Figure 3. The ceramic tile GPN and an example of embeddedness at two territories (or clusters). 
(a) All the knowledge flows from within the GPN influence the clusters' development, which evolve dynamically. For instance, the flows of knowledge based on new inkjet technology transform each cluster step-by-step, including those in Italy and Spain. Each cluster's context (including cultural and institutional influences, type of ties and architectural knowledge) moderates the absorption of new knowledge from within the GPN.

(b) The Castellon MNEs act as gatekeepers (for the frits and decoration processes), bringing knowledge from Castellon to each cluster, and from all around the world to Castellon, especially market knowledge, trends and customer requirements. In fact, the Castellon MNEs' affiliates act as network orchestrators in each cluster (for the decoration process), bringing cutting edge knowledge from abroad to each cluster. These companies are the nodes which connect territories and articulate the GPN.

(c) All in all, each meso-stage (or cluster) of the GPN has a particular context and architectural knowledge. Therefore, the way in which the Castellon frits MNEs adapt to each territory involves different FDI strategies, as predicted in the IB literature. In addition, the MNEs are responsible for the main knowledge flows among the involved territories, acting as a glue to hold all different territories of the GPN. ${ }^{3}$ See Figure 3 for a representation of the idea of MNEs' articulation of clusters along GPNs.

\section{Conclusion}

The GVC perspective of inter-firm relationships (as proposed, e.g., by Gereffi, 1994) has been applied to the territory (by scholars such as Humphrey \& Schmitz, 2002) with the aim of enriching our understanding of the local-global connection, becoming adopted in the EG strand. In parallel, the GPN perspective (Coe et al., 2004) has complemented the GVC approach and overcome static and linear GVC assumptions, while embracing and making explicit the rich complexity of territories that are inserted into (through their ties, networks and institutions) the global networks. Thus a more "meso" (and local) emphasis has been added to the "global" perspective.

Nevertheless, neither the GVC nor the GPN perspective can describe all the elements necessary to fully understand the meso-global spaces. Our theoretical integration of the IB and EG perspectives is an attempt to overcome the hitherto paucity of theoretical insights about meso-global spaces. This paucity has arisen for several reasons, including because: (1) despite the usefulness of the GPN approach, the EG literature provides plenty of empirically driven cases but is weak on providing a clear theoretical integration to tackle the local-global connection of clusters; (2) the EG perspective has not adequately brought the concept of the "firm", as a micro-unit of analysis, into the conversation, especially when using the GPN approach and (3) the role of multinational firms in connecting territories is not properly articulated in the EG perspective even though MNEs are recognized as key agents for connecting territories together.

The rationale for our theoretical integration derives from a recognition of the vital role that the concept of the "firm" plays in local-global connections, but which is yet absent in the EG literature, which is especially noticeable in the GPN framework. Above all, the paper addresses the following key point. This is that it is crucial to explore, and framework, our understanding of organizational and co-location decisions "in tandem", in order to better understand local-global connections made through multinational firms 
which co-locate in, and connect, clusters, articulating thus GPNs. The rationale for this cross-field integration is based on the fact that the roles of firms, and especially MNEs, are at the very centre of the local-global phenomenon, but that, to the best of our knowledge, the EG literature has not sufficiently addressed this fact (Coe et al., 2008). By drawing on the theoretical intersection of different disciplines related to concepts of external linkages, global pipelines or connected meso-global territories, it has been possible to produce a fertile conceptual integration which can clarify and extend the fundamentals of the GPN idea for an EG audience.

Our empirical study of the ceramics tiles industry has revealed that linkages between clusters come from the co-locating of MNEs which act as technological gatekeepers, disseminating knowledge between stages (territories or clusters) along the GPNs. Then, the recombination of external and local knowledges, deriving from both local ties and interactions between local firms and MNEs, form new knowledge also, which is cluster dependent due to the particular context (such as specific forms of governance mechanisms, the power distribution of agents, the role of institutions and the particular local social, political and cultural circumstances) and architectural knowledge of each cluster. Part of this locally created knowledge will be also disseminated within the internal MNEs networks and finally will be transferred, totally or partially, to other clusters along the GPN.

In summary, it can be stated that

- the flows of knowledge within a GPN influence clusters and drive them to evolve dynamically;

- for each cluster, the FDI activities of subsidiaries of ceramic tiles MNEs that are colocated vary, according to the specific nature of the agglomeration. The activities of the subsidiaries are fitted to the local externalities, confirming Rugman et al. (2011);

- each ceramic tiles cluster has a different context and architectural knowledge (as suggested by Storper, 2009; Tallman \& Chacar, 2011), which serves to moderate both the absorption and creation of new knowledge.

The implications of this paper are two-fold. Firstly, policymakers should be aware of the importance of clusters' external linkages, which are usually overlooked (Bathelt et al., 2004). The flow of knowledge from MNEs should be given institutional support, and policymakers and practitioners should understand which types of knowledge or externalities can be best used to attract FDI by those MNEs which can benefit particular clusters. In addition, policymakers need to understand the process in a dynamic way, recognizing that a local cluster's strength evolves over time and that conditions for evolution can change according to the particular external-to-the-cluster environment, including, especially, the effects of distant clusters along the GPN.

Secondly, scholars need to be more precise about how they use the concept of external linkages, making it more operationally useful. In fact, external linkages (or global pipelines) have to be defined and measured, as an additional component of a cluster's competitive advantage. Included is a need to define the type of knowledge that is conveyed through external linkages, addressing whether it is new to the industry or to the cluster. In addition, scholars from the field of EG need to embrace a more eclectic framework for addressing the topic, and be open to benefit from dialogue with different economic perspectives such as that of IB and its deep knowledge of MNEs. In particular, the EG perspective and the GPN perspective alike can be strengthened by the inclusion of ideas from the IB literature, 
especially in respect of the role of MNEs in connecting clusters and territories and in configuring GPNs.

This paper is, however, not free from limitations. First, the specificity of the clusters investigated as "ceramics clusters" may limit the generalization of results. Second, the use of a qualitative methodology can also be a shortcoming. For future studies, theorydriven empirical cases are needed in order to formalize and develop insights about cluster external sources of knowledge and the way in which MNEs contribute to them.

\section{Acknowledgements}

We are very thankful to the "Ministry of Economics" funding ECO2010:17318 and "Generalitat Valenciana" for its support in visiting the London School of Economics and Political Science (BEST 2011 grants).

\section{Notes}

1. In order to simplify, we follow Gordon and McCann (2000) and use the notion of cluster in a wide sense that includes pure agglomeration clusters, complexes à la Porter (1990) and social networks such as industrial districts.

2. The economic rationale of the asymmetric distribution of knowledge between spaces is provided by Storper's (2009) distinction and separation of the Marshall-Arrow externalities from those of Romer, drawing on growth theory. See Storper (2009) for more details.

3. Castellon firms (big five, excluding Colorobbia, Italian firm), activities off-shored to Sassuolo: sales and technical customer service. Principal FDI types: market seeker. Castellon firms (big five), activities offshored to Brazilian clusters: sales and technical customer service; production (complex, fusion frits); administration, innovation (product development, with no R\&D). Principal FDI types: market seeker; efficiency seeker.

\section{References}

Albors-Garrigos, J. \& Hervas-Oliver, J. L. (2012) Radical innovation and technology diffusion in traditional clusters: How high-tech industries reinvented a traditional cluster, in: T. G. Bas \& J. Zhao (Eds) Technology Firms in Developed and Developing Countries: Cluster Growth Initiatives, pp. 99-110 (Hershey, PA: IGI Global).

Anfacer (2011) Revestimentos Ceramicos do Brasil. Sao Paulo. Available at www.anfacer.org.br (accessed 7 October 2011).

Ascer (2010) Ceramic Tile Report, Castellon: Ascer. Available at www.ascer.es (accessed 1 May 2010).

Assopiastrelle (2011) Indagine Statistiche sul 2010, Confindustria Ceramica, Sassuolo: Assopiastrelle. Available at www.assopiastrelle.it (accessed 1 August 2011).

Bathelt, H., Malmberg, A. \& Maskell, P. (2004) Clusters and knowledge: Local buzz, global pipelines and the process of knowledge creation, Progress in Human Geography, 28(1), pp. 31-56.

Becattini, G. (1990) The Marshallian district as a socio-economic notion, in: F. Pyke, G.Y. Becattini \& W. Sengenberger (Eds) Industrial Districts and Inter-firm Co-operation in Italy, pp. 37-51 (Geneva: OMT).

Belussi, F. \& Asheim, B. T. (2010) Industrial districts and globalisation: Learning and innovation in local and global production and innovation systems, in: F. Belussi \& A. Sammarra (Eds) Business Networks in Clusters and Industrial Districts: The Governance of the Global Value Chain, pp. 246-265 (London: Routledge).

Beugelsdijk, S., McCann, P. \& Mudambi, R. (2010) Place, space and organization-Economic geography and the multinational enterprise, Journal of Economic Geography, 10(4), pp. 485-493.

Coe, N. M., Hess, M., Yeung, H. W.-C., Dicken, P. \& Henderson, J. (2004) Globalizing regional development: A global production networks perspective, Transactions of the Institute of British Geographers, 29(4), pp. $468-484$. 


\section{J.-L. Hervas-Oliver \& R. Boix-Domenech}

Coe, N. M., Dicken, P. \& Hess, M. (2008) Introduction: Global production networks—debates and challenges, Journal of Economic Geography, 8(3), pp. 267-269.

Cooke, P. (2005) Regional asymmetric knowledge capabilities and open innovation, Research Policy, 34(8), pp. 1128-1149.

Dunning, J. H. (2009) Location and the multinational enterprise: John Dunning's thoughts on receiving the JIBS 2008 decade award, Journal of International Business Studies, 40(1), pp. 20-34.

Eisenhardt, K. (1989) Building theories from case study research, Academy of Management Review, 14(4), pp. $532-550$.

Gereffi, G. (1994) The organization of buyer-driven global commodity chains: How US retailers shape overseas production networks, in: G. Gereffi \& M. Korzeniewicz (Eds) Commodity Chains and Global Capitalism, pp. 78-104 (London: Praeger).

Gereffi, G., Humphrey, J. \& Sturgeon, T. (2005) The governance of global value chains, Review of Political Economy, 12(1), pp. 78-104.

Gertler, M. \& Levitte, Y. M. (2005) Local nodes in global networks: The geography of knowledge flows in biotechnology innovation, Industry \& Innovation, 12(4), pp. 487-507.

Gibbon, P. \& Ponte, S. (2005) Trading Down: Africa, Value Chains, and the Global Economy (Philadelphia, PA: Temple University Press).

Gordon, I. R. \& McCann, P. (2000) Industrial clusters: Complexes, agglomeration and/or social networks? Urban Studies, 37(3), pp. 513-532.

Henderson, R. \& Clark, K. B. (1990) Architectural innovation: The reconfiguration of existing product technologies and the failure of established firms, Administrative Science Quarterly, 35(1), pp. 9-30.

Henderson, J., Dicken, P., Hess, M., Coe, N. M. \& Yeung, H. W.-C. (2002) Global production networks and the analysis of economic development, Review of International Political Economy, 9(3), pp. 436-446.

Hervas-Oliver, J. L. \& Albors-Garrigos, J. (2007) Do clusters capabilities matter? Empirical evidence in European clusters, Entrepreneurship and Regional Development, 19(1), pp. 113-136.

Hervas-Oliver, J. L. \& Albors-Garrigos, J. (2008) Local knowledge domains and the role of MNE affiliates bridging and complementing cluster's knowledge, Entrepreneurship and Regional Development, 20(6), pp. 581-598.

Hervas-Oliver, J. L. \& Albors-Garrigos, J. (2009) The role of the firm's internal and relational capabilities in clusters: When distance and embeddedness are not enough to explain innovation, Journal of Economic Geography, 9(2), pp. 263-283.

Hervás-Oliver, J. L., Albors-Garrigós, J. \& Dalmau-Porta, J. I. (2008) External ties and the reduction of knowledge asymmetries among clusters within global value chains: The case of the ceramic tile district of Castellon, European Planning Studies, 16(4), pp. 507-520.

Humphrey, J. \& Schmitz, H. (2002) How does insertion in global value chains upgrading in industrial clusters? Regional Studies, 36(9), pp. 1017-1027.

Jenkins, M. \& Tallman, S. (2010) The shifting geography of competitive advantage: Clusters, networks and firms, Journal of Economic Geography, 10(4), pp. 599-618.

Maskell, P. \& Malmberg, A. (2007) Myopia, knowledge development and cluster evolution, Journal of Economic Geography, 7(5), pp. 603-618.

McCann, P. \& Mudambi, R. (2004) The location decision of the multinational enterprise: Some theoretical and empirical issues, Growth \& Change, 35(4), pp. 491-524.

Meyer, K. E., Mudambi, R. \& Narula, R. (2011) Multinational enterprises and local contexts: The opportunities and challenges of multiple embeddedness, Journal of Management Studies, 48(2), pp. 235-252.

Meyer-Stamer, J., Maggi, C. \& Seibel, S. (2004) Upgrading the tile industry of Italy, Spain, and Brazil: Insights from cluster and value chain analysis, in: H. Schmitz (Ed.) Local Enterprises in the Global Economy, pp. 174-199 (Cheltenham: Edward Elgar).

Murphy, J. T. \& Schindler, S. (2011) Globalizing development in Bolivia? Alternative networks and valuecapture challenges in the wood products industry, Journal of Economic Geography, 11(1), pp. 61-85.

Nachum, L. \& Keeble, D. (2003a) MNE linkages and localised clusters: Foreign and indigenous firms in the media cluster of Central London, Journal of International Management, 9(2), pp. 171-192.

Nachum, L. \& Keeble, D. (2003b) Neo-Marshallian clusters and global networks, Long Range Planning, 36(5), pp. 459-480.

Nadvi, K. \& Halder, G. (2005) Local clusters in global value chains: Exploring dynamic linkages between Germany and Papista, Entrepreneurship and Regional Development, 17(3), pp. 339-363. 
Nelson, R. \& Winter, S. (1982) An Evolutionary Theory of Economic Change (Cambridge, MA: Harvard University Press).

Pavitt, K. (1984) Sectoral patterns of technical change: Towards a taxonomy and a theory, Research Policy, 13(6), pp. 343-373.

Pinch, S., Henry, N., Jenkins, M. \& Tallman, S. (2003) From "industrial districts" to "knowledge clusters": A model of knowledge dissemination and competitive advantage in industrial agglomerations, Journal of Economic Geography, 3(4), pp. 373-388.

Porter, M. (1990) The Competitive Advantage of Nations (New York: The Free Press).

Rugman, A. \& Verbeke, A. (2001) Subsidiary-specific advantages in multinational enterprises, Strategic Management Journal, 22(3), pp. 237-250.

Rugman, A., Verbeke, A. \& Yuan, W. (2011) Re-conceptualizing Bartlett and Ghoshal's classification of national subsidiary roles in the multinational enterprise, Journal of Management Studies, 48(2), pp. 253-277.

Russo, M. (2004) The ceramic industrial district facing the challenge from China. Working paper for the research project Distretti industriali come sistemi complessi, Universita di Modena, Italy.

Storper, M. (2009) Reopke lecture in economic geography regional context and global trade, Economic Geography, 85(1), pp. 1-21.

Storper, M. \& Venables, A. J. (2004) Buzz: Face-to-face contact and the urban economy, Journal of Economic Geography, 4(4), pp. 351-370.

Talbot, J. (2002) Tropical commodity chains, forward integration strategies and international inequality: Coffee, cocoa and tea, Review of international Political Economy, 9(4), pp. 701-734.

Tallman, S. \& Chacar, A. S. (2011) Knowledge accumulation and dissemination in MNEs: A practice-based framework, Journal of Management Studies, 48(2), pp. 201-210.

Tallman, S., Jenkins, M., Henry, N. \& Pinch, S. (2004) Knowledge clusters and competitive advantage, Academy of Management Review, 29(2), pp. 258-271.

Weller, S. (2008) Beyond global production networks: Australian fashion week's trans-sectoral synergies, Growth and Change, 39(1), pp. 104-122.

Yin, R. K. (2008) Case Study Research, Applied Social Research Series, Vol. 5, 4th ed. (London: Ed SAGE). 